\title{
Risk Aversion, Risk Preference and Farmers' Decision to Participate in Broiler Contract Farming: A Case Study in Jember, Indonesia
}

\author{
Mohammad Rondhi*, Joni Murti Mulyo Aji, Ahmad Fatikhul Khasan, \\ Adinda Tissa Rachmasari Putri and Rizky Yanuarti \\ Department of Agribusiness, Faculty of Agriculture, Universitas Jember, Jember, Indonesia \\ *Corresponding author: rondhi.faperta@unej.ac.id
}

\begin{abstract}
The demand for broiler is rising rapidly due to its capability as the main animal protein source. In contrast, the production of broiler meat is unstable due to the possibility of farm risk. Contract Farming (CF) is one of the risk management tools for farmers but has not been used effectively. The purpose of this study was to analyze the factors that influence farmers' decision to participate in CF. The analysis used six independent variables, namely farmer's age, farm size, household size, education, farmer's risk preference and risk aversion level. This study used primary data from 70 broiler farmers in Jember, which were divided into two groups, contract farmer and independent farmer. Each group had the same number of respondents. The results show that five among six independent variables significantly affected farmers' decision to take part in CF. Farmer's age decreased farmer's probability to participate in $\mathrm{CF}$, while education, farm size, household size and risk preference had positive effects. Farmer's risk aversion level did not have any significant effect. The results suggest that the effort to expand CF participation should focus on young and educated farmers with large farm size.
\end{abstract}

Keywords: broiler; contract farming; risk aversion; risk preference

Cite this as: Rondhi, M., Aji, J. M. M., Khasan, A. F., Putri, A. T. R., \& Yanuarti, R. (2020). Risk Aversion, Risk Preference and Farmers' Decision to Participate in Broiler Contract Farming: A Case Study in Jember, Indonesia. Caraka Tani: Journal of Sustainable Agriculture, 35(1), 98-107. doi: http://dx.doi.org/10.20961/ carakatani.v35i1.37964

\section{INTRODUCTION}

Broiler is one of the commodities that contribute to national economy. Broiler farming has excellent prospects for development both on large and small scale production. The broiler farming period is relatively short compared to other livestock commodities. Broiler are harvested at an average age of 35 days. The rapid production process of broiler farming has attracted the attention of community and investors (Sunarno et al., 2017).

Broiler is the primary source of animal protein for the majority of Indonesians. Its annual consumption in 2018 was $5,566 \mathrm{~kg}$ per capita. The average consumption growth in the period of
2014-2018 was $8.99 \%$ (Pusat Data dan Sistem Informasi Pertanian, 2018). Public consumption of broilers has the greatest value compared to the consumption of other meat commodities. However, people's dependence to consume broiler meat must be balanced with the number of broiler production.

In contrast to the increasing demand, broiler production is unstable and fluctuating. Fluctuating broiler production is also an indication that high production risk exists in the farming process. Production risk can be caused by human resources, production inputs and natural factors. The high production risk is due to broiler's vulnerability to diseases that causes high

\footnotetext{
* Received for publication December 14, 2019 Accepted after corrections January 29, 2020
} 
losses for broiler breeders. It is not the only risk of production in broiler farming but also a price risk. Price risk can arise due to the instable selling prices. This type of risk occurs because the price received by the farmer is directly related to the traders' decision, which causes the farmers to become price takers in determining the price of broilers (Widjayanti and Rizal, 2014).

The high production and price risks have caused farmers to make decisions to overcome farming risks. Several farmers decide to participate in contract farming (CF) but some others run broiler farming independently. The partnership of farmer and company can take forms of production contract and marketing contract (Schipmann and Qaim, 2011; Boadu, 2016). Production contracts include the provision of inputs for broiler farming such as DOC, feed, vaccines and medicines. The marketing contract is carried out when the broiler produces production. The marketing contract requires the farmer to sell the production of broiler to the company at a price that has been settled at the beginning of the contract.

According to Government Regulation of the Republic of Indonesia Number 44 Year 1997, CF is a business collaboration between small businesses and medium businesses and/or with large businesses accompanied by coaching and development by medium businesses and/or large businesses based on the principles of mutual need, mutual strengthening and mutual benefit. These make CF profitable for both parties. For farmers with a partnership, the availability of capital will be easier to ensure, and hence, the cultivation activities carried out can run smoothly. In addition, farmers require a market in selling their products. For partner companies, meeting the target capacity of broilers is highly necessary to meet the market demand. The existing partnership patterns can be divided into several types, namely plasma core, sub-contract, general trading, agency and franchise.

The purpose of this study was to determine the factors contributing to the farmers' decision to participate in $\mathrm{CF}$. The topic becomes relevant since broilers are the most consumed animal protein sources in Indonesia but their production remains volatile. Furthermore, the participation rate of broiler farmers in CF was only $56.69 \%$ (BPS, 2014). Thus, there is a great opportunity for CF expansion. Although CF provides beneficial features, most farmers in Indonesia are reluctant to participate in CF since the farmers can lose their independence in making farm decisions and the privileges to own the products (Key, 2005).

$\mathrm{CF}$ is an important instrument for agricultural development. A group of empirical literature have been summarized in Otsuka et al. (2016); Bellemare and Bloem (2018); Ton et al. (2018) that $\mathrm{CF}$ is an effective instrument to coordinate agricultural value chain and improve the quality of agricultural product. In addition, CF is the contributor to the effort to establish a sustainable agricultural system since one of the primary keys in sustainable agricultural system is an efficient agricultural value chain (Kamble et al., 2020)

The research related to the factors that influence farmers' decisions to participate in $\mathrm{CF}$ have been conducted by Akinola (2014) and Wainaina et al. (2014). Factors that were found to be influential were generally related to demographic and economic variables of the farmers such as age, education, farming experience, income, number of family members, company participation and access to credit, farm size and length of partnership. While the studies related to the risks encountered by farmers have been widely carried out. Akinola (2014) and Mao et al. (2019) analyzed the risk preferences of farmers using regression functions and utility functions.

In previous studies, identification of factors that influenced farmers' decisions to partner was only done by looking at demographics and socioeconomic variables without considering the farmer's risk preference and risk aversion. Whereas, in terms of risk, preceding studies only measured the risk preferences of farmers without discussing the level of risk aversion of farmers. Thus, the novelty of this study lies in the use of new methods to approach farmers' risk preferences and the use of farmer attitude towards risk as a predictor for farmer participation in $\mathrm{CF}$. Moreover, few studies in Indonesia have explored the effect of farmer risk attitude on $\mathrm{CF}$ participation.

\section{MATERIALS AND METHOD}

\section{Data collection}

The study was conducted in February-April 2019 in Jember, East Java. Jember was selected as the location of the research because it is one of the broiler production centre in East Java. There were seven sub-districts in the research area, namely 
Bangsalsari, Sumbersari, Pakusari, Kalisat, Sukowono, Ledokombo and Mumbulsari. The distribution of the locations is presented in Figure 1.

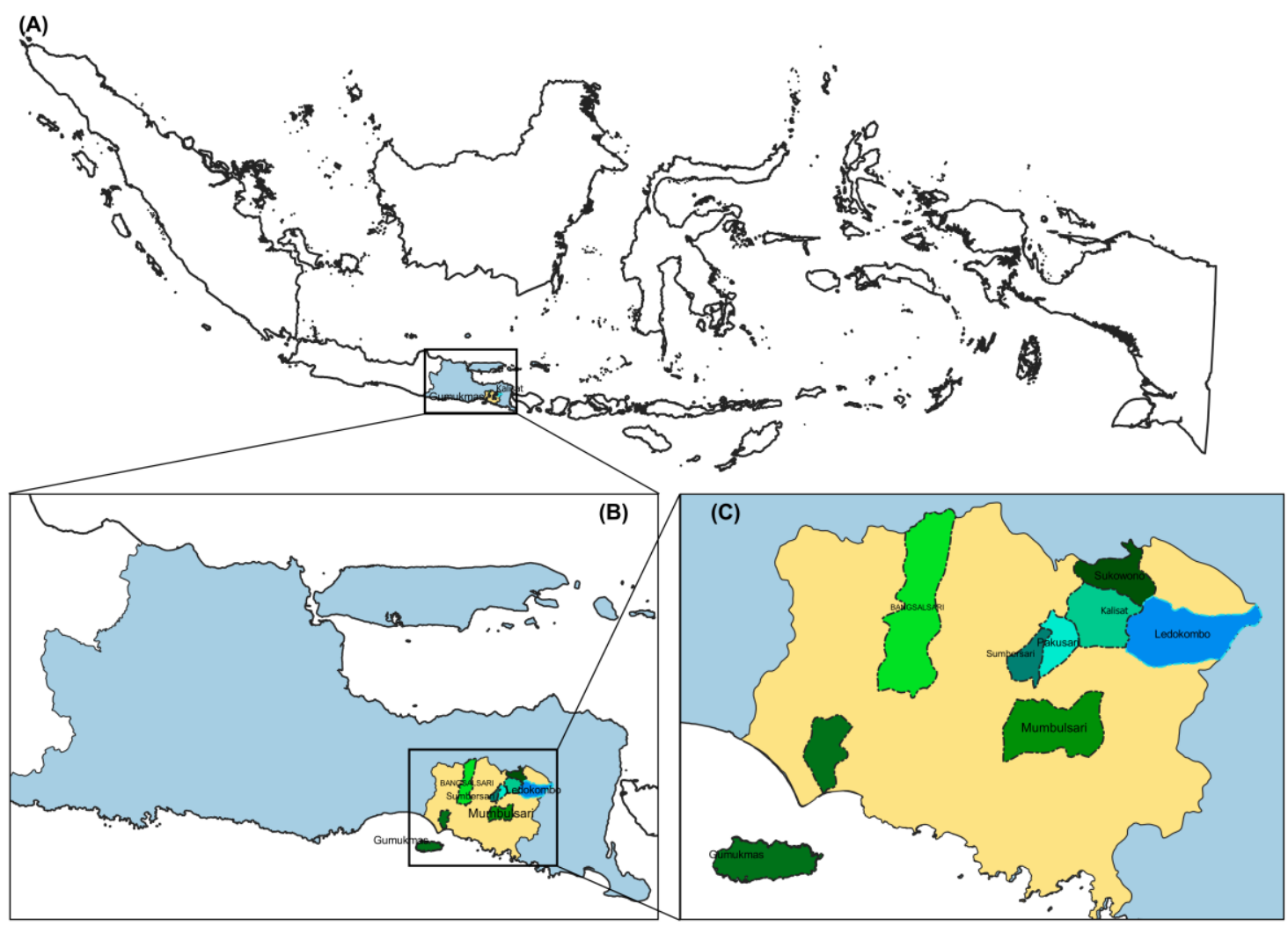

Figure 1. Distribution of research location in Jember

The population of broiler farmers in Jember was formally unidentified, and therefore, quota sampling was employed to determine the sample size. There were two sample groups, namely CF participants and independent farmer, each of which with broiler farmers. The determination of respondent was based on farmers' partnership with PT XYZ. PT XYZ is an integrator that links broiler farmers and feed suppliers. This company operates mainly in Jember. The CF participants were selected randomly from a list provided by PT XYZ, while independent farmers were selected by snowball sampling with a criterion that the farmers included in this study were who practiced independent broiler farming. Before carrying out a logistic regression analysis, Method of Successive Interval (MSI) analysis was performed to calculate the value of farmers' risk preferences and farmers' risk aversion level.

\section{Farmer risk preference}

The ordinal data obtained using Likert scale instruments were used, in which respondents were asked to fill out questionnaires and give grades of agreement to the presented statements between 4 to -4 . Value 4 (extremely agree), 3 (strongly agree), 2 (agree), 1 (moderate agree), 0 (neutral), -1 (moderate disagree), -2 (disagree), -3 (strongly disagree) or -4 (extremely disagree) was given on each statement (Vassalos and $\mathrm{Li}, 2016$ ). The statements that represent broiler farmers' preference towards risk are summarized in Table 1.

Table 1. The statements that represent broiler famers risk preference

\begin{tabular}{cl}
\hline No. & Statement \\
\hline 1. & I would rather play safe than take a risk \\
2. & I avoid taking risks \\
3. I prefer certainty over uncertainty \\
4. & I do not like to take risks
\end{tabular}

Sources: Vassalos and Li (2016) and Franken et al. (2012)

The average value of breeders was used to determine the preferences of broiler farmers in facing risks. If the average value is positive, the breeders are classified as risk averse; if the 
average value is $=0$, the breeders are classified as risk neutral and if the average value is negative, the breeders are classified as risk takers.

\section{Risk aversion level}

The farmer risk aversion level was obtained with questions through illustrations or simulations. The illustrations of questions were based on the model proposed by Vassalos and $\mathrm{Li}$ (2016). The questions were adjusted to the conditions of the broiler farmers in the study area. The data attained were the ordinal data from 1 to 6 , which were labeled from $\mathrm{A}$ to $\mathrm{F}$ in sequence. After that, the data were converted into intervals using the MSI.

The questions provided to farmers are as follows: If you have 5 broiler cages, assuming that each cage has a population of 5,000 broilers, then you are given several options to choose.

a. Register your entire enclosure to join the partnership.

b. Register some of your cages for part of the partnership.

c. Do not register your entire enclosure (do not participate in $\mathrm{CF}$ ).

There was a difference between the purchase price of the cages included in the $\mathrm{CF}$ and the price of the cages that were not involved in the CF. If a farmer decided to participate in $\mathrm{CF}$, the farmer would sell the production at contract price, which was agreed in the beginning of production. If the farmer decided not to participate in $\mathrm{CF}$, the farmer would sell the production at market price, which was not informed to farmer in the beginning of production. The average contract price was lower than market price. However, the contract price had a stable and predictable value. Meanwhile, market price fluctuated, following the market conditions. There would be a time when market price was significantly higher than contract price. In some occasion, the market price would fall below the contract price. Price risk was realized when the market price was lower than contract price.

In a good market condition, the production from the cage that was not included in CF would have a higher selling price since market price was higher than contract price. In this condition, the product that was not involved in CF was valued at IDR 25,000,000 per cage. This means that farmer would receive a revenue of IDR 25,000,000 per cage. Conversely, in a critical market condition, the market price would fall to IDR 0 per cage. In this situation, the farmer would not receive any revenue. The production from the cages that included in $\mathrm{CF}$ would have a lower but stable selling price of IDR 17,500,000 per cage. The selling price remained constant both in good and bad market conditions. Thus, each contracted cage would give farmer a revenue of IDR 17,500,000. Table 2 illustrates the various combinations of the number of cages which were included in and excluded from $\mathrm{CF}$.

Table 2. The combinations of cages which included in and excluded from the CF

\begin{tabular}{cccccc}
\hline \multirow{2}{*}{ Criteria } & \multicolumn{2}{c}{$\begin{array}{c}\text { Number of cages } \\
\text { (pieces) }\end{array}$} & \multicolumn{2}{c}{$\begin{array}{c}\text { Expected revenue } \\
\text { (millions IDR) }\end{array}$} & \\
\cline { 2 - 5 } & $\begin{array}{c}\text { Not include } \\
\text { in CF }\end{array}$ & $\begin{array}{c}\text { Include in } \\
\text { CF }\end{array}$ & $\begin{array}{c}\text { If the price risk } \\
\text { doesn't occur (50\%) }\end{array}$ & $\begin{array}{c}\text { If the price risk } \\
\text { occurs }(50 \%)\end{array}$ & \\
\hline A & 0 & 5 & 0.0 & 87.5 & Extreme \\
B & 1 & 4 & 95.0 & 70.0 & Severe \\
C & 2 & 3 & 102.5 & 52.5 & Intermediate \\
D & 3 & 2 & 110.0 & 35.0 & Moderate \\
E & 4 & 1 & 117.5 & 17.5 & Slight to neutral \\
F & 5 & 0 & 125.0 & 0.0 & Neutral to negative \\
\hline
\end{tabular}

Source: Vassalos and Li (2016)

\section{Factors influencing farmers' decision}

Logistic regression was applied to scrutinize the factors contributing to the decision of broiler breeders to participate. There were six variables used, namely age (year), business scale (head), household scale (person), education (year), risk preference and risk aversion level. The use of economic and social demographic variables such as age, business scale, household scale and education were also found in previous studies (Akinola, 2014; Pandey, 2016). This study added the use of risk preference and risk aversion levels to complete the explanation of the effect of farmers' risk attitude on farmers' decisions. The 
model of logistic regression used in this analysis is detailed below.

$$
\begin{gathered}
Y_{i}=\ln \left(\frac{p_{i}}{1-p_{i}}\right) \\
=\frac{e^{b 0+b_{1} X_{1}+b_{2} X_{2}+b_{3} X_{3}+b_{4} X_{4}+b_{5} X_{5}+b_{6} X_{6}}}{1+e^{b 0+b_{1} X_{1}+b_{2} X_{2}+b_{3} X_{3}+b_{4} X_{4}+b_{5} X_{5}+b_{6} X_{6}}}
\end{gathered}
$$

$Y$ was the farmer's decision to participate in $\mathrm{CF}(1=$ participant; $0=$ non-participant $)$ and $\mathrm{X}_{1-6}$ was the independent variable, $\mathrm{b}_{0}$ was the constant, $b_{1-6}$ was the coefficient of each independent variable. The complete explanations of the used independent variables are depicted in Table 3. Before interpreting the results of a logistic analysis, it was necessary to test the accuracy of the created model by looking at the value of the Omnibus Test of Model Coefficients and -2 loglikelihood. If the value of the Omnibus Test of Model Coefficients was significant and the likelihood value decreased from block 0 to block 1 , then the model was fit.

Table 3. The description of logistic regression variable on farmer decision to participate in $\mathrm{CF}$ in

\begin{tabular}{|c|c|c|c|c|}
\hline & Factor & Description & Units & Measure \\
\hline $\mathrm{Y}$ & $\begin{array}{l}\text { Decision to } \\
\text { participate in } \mathrm{CF}\end{array}$ & $\begin{array}{l}\text { Farmers decision to participate in } \mathrm{CF}(1=\text { participate, } \\
0=\text { do not participate })\end{array}$ & - & Nominal \\
\hline $\mathrm{X}_{1}$ & Age & $\begin{array}{l}\text { Farmers' age in the year when the research was } \\
\text { conducted }\end{array}$ & Year & Scale \\
\hline $\mathrm{X}_{2}$ & Farm size & $\begin{array}{l}\text { The number of broilers in the year when the research } \\
\text { was conducted }\end{array}$ & Bird & Scale \\
\hline$X_{3}$ & Household size & $\begin{array}{l}\text { The number of family members in each farm } \\
\text { household }\end{array}$ & Person & Scale \\
\hline $\mathrm{X}_{4}$ & Education & $\begin{array}{l}\text { Years in formal education from not going to school } \\
\text { to master/doctor graduate }\end{array}$ & year & Scale \\
\hline $\mathrm{X}_{5}$ & Risk preference & Farmers' preference in facing risk & - & Ordinal \\
\hline $\mathrm{X}_{6}$ & Risk aversion level & $\begin{array}{l}\text { RAL was obtained by using the question method with } \\
\text { assumptions, according to the research conducted by } \\
\text { Vassalos and Li (2016). There were six responses that } \\
\text { could be chosen by farmers, each of which had a } \\
\text { value ranging from } 1 \text { to } 6\end{array}$ & MSI & Scale \\
\hline
\end{tabular}
Indonesia in 2019

\section{RESULTS AND DISCUSSION}

The descriptive statistics of the variables can be seen in Table 4. CF participants had younger age and higher education levels than nonparticipants. The CF participants most likely handled bigger farm-scale than non-participants and this could be measured from the farm size. $\mathrm{CF}$ participants had higher farm size. The household size of CF participants was larger than nonparticipants. Farmers who participated in $\mathrm{CF}$ also had higher risk preferences and risk aversion level.

Table 4. Descriptive statistics of variables in the model

\begin{tabular}{llrrrr}
\hline & \multicolumn{1}{c}{ Variable } & \multicolumn{2}{c}{ Participating in CF } & \multicolumn{2}{c}{ Not participating in CF } \\
\hline & & $\begin{array}{r}\text { Standard } \\
\text { deviation }\end{array}$ & Mean & $\begin{array}{r}\text { Standard } \\
\text { deviation }\end{array}$ \\
\hline $\mathrm{X}_{1}$ & Age (year) & 44.57 & 1.72 & 60.80 & 1.73 \\
$\mathrm{X}_{2}$ & Farm size (bird) & 6428.57 & 667.41 & 2574.29 & 703.29 \\
$\mathrm{X}_{3}$ & Household size (person) & 5.26 & 0.23 & 3.14 & 0.23 \\
$\mathrm{X}_{4}$ & Education (year) & 10.78 & 0.49 & 6.46 & 0.31 \\
$\mathrm{X}_{5}$ & Risk preference & 3.44 & 0.18 & 2.29 & 0.16 \\
$\mathrm{X}_{6}$ & Risk aversion level & 1.98 & 0.11 & 2.55 & 0.17 \\
\hline
\end{tabular}


The logistic regression estimation produced a robust result and five of six of the input variables had a statistically significant effect at the $95 \%$ confidence level. As presented in Table 5, the value of the Omnibus Test of Model Coefficients or Chi-Square had a significance of $0.000(<0.01)$. This significance means that with a confidence level of $99 \%$, there was at least one independent variable influencing the dependent variable. The overall percentage value indicated the regression model used was quite good. It was able to correctly estimate $95.7 \%$ of the conditions that occurred in the study area (Table 6). There was a decrease in the Likelihood value from block number 0 to block number 1 . This means that the regression model performed better at predicting farmers' decision to participate in CF. In other words, the addition of independent variables to the model significantly improved the model so that the used model was good and appropriate to describe the factors putting effect on farmers' decision to join $\mathrm{CF}$.

Table 5. The logistics regression output of factors contributing to farmers' decision to participate in $\mathrm{CF}$ (predictors)

\begin{tabular}{lcclc}
\hline \multicolumn{1}{c}{ Variable } & $\mathrm{B}$ & S.E. & t-value & Exp (B) odds ratio \\
\hline Age (year) & -0.311 & 0.154 & $0.044^{*}$ & 0.733 \\
Farm size (bird) & 0.001 & 0.000 & $0.063^{*}$ & 1.001 \\
Household size (person) & 1.778 & 1.019 & $0.081^{*}$ & 5.921 \\
Education (year) & 0.773 & 0.458 & $0.091^{*}$ & 2.166 \\
Risk aversion level $\left(\mathrm{X}_{5}\right)$ & -3.74 & 0.966 & 0.699 & 0.688 \\
Risk preference $\left(\mathrm{X}_{6}\right)$ & 2.650 & 1.417 & $0.062^{*}$ & 14.149 \\
Constant & -5.317 & 5.285 & 0.314 & 0.005 \\
\hline
\end{tabular}

Note: $\quad * *$ : significant at $99 \%$ confidence level

* : significant at $95 \%$ confidence level

Table 6. The logistics regression output of factors contributing to farmers' decision to participate in CF (Model Goodness of Fit Tests)

\begin{tabular}{lc}
\hline Test & Value \\
\hline Omnibus Test of Model Coefficient & $0.000^{* *}$ \\
Nagelkerke R square & 0.937 \\
-2 Log likelihood (step 0) & 97.041 \\
-2 Log likelihood (step 1) & 12.100 \\
Classification table (overall) & $95.7 \%$ \\
\hline Note: $\quad * *:$ significant at 99\% confidence level \\
$\quad * \quad$ : significant at 95\% confidence level
\end{tabular}

Farmer age had a negative influence on farmer decision to participate in $\mathrm{CF}$. Odds ratio value (Exp (B)) of age was 0.733 means that older farmer had a lower tendency to play a part in $\mathrm{CF}$ by 0.733 times compared to younger farmer, assuming that the other variables were constant. The younger farmers would tend to choose to participate in CF. This was because young farmers had an open mind in the latest developments in agriculture, especially the model of CF. On the other hand, older farmers were difficult and reluctant to accept new developments such as adopting the concept of $\mathrm{CF}$ in broiler farming. Vassalos and $\mathrm{Li}$ (2016) have also stated that older farmers are less likely to be involved in CF. This is because in older age, farmers will be difficult to commit long-term contracts or agreements and they have less willingness to trust others to handle their farming process.

Farm size had a positive influence on farmers' decisions to participate in $\mathrm{CF}$. The odds ratio value was 1.001, meaning that farmers with larger farm size had a tendency to participate in CF by 1.001 times compared to farmer with smaller farm size, assuming the other variables were in a constant state. The farmers with large farm size would consider that when a failure occurred, it would cause large losses. In order to reduce damages, the breeders choose to share the risk of loss with the company through CF. On the contrary, farmers with smaller farm size argued that when a failure occurred, it would lead to a relatively smaller loss. Farmers believed that participating in CF was not necessary. This is in line with Arumugam et al. (2011); Franken et al. (2012); Hu (2012) and MacDonald and Korb (2012), who have detailed that large scale farming tends to encourage farmers to protect their businesses by participating in CF. However, a negative effect of farm size on CF participation 
was found on farmers who had a contract with supermarket in China (Miyata et al., 2009).

Household size had a positive effect on farmers' decision to participate in CF. The odds ratio of household size was 5.921, signifying that farmers with larger household sizes would have the tendency to participate in CF by 5.921 times more, compared to farmers with smaller household size, assuming that the other variables were in a constant state. This is different from Akinola (2014), who has stated that the larger the household size is, the less likely it is for farmer to participate in CF. In the research area, farmers with larger household size tended to think that the living cost would also increase. Therefore, they required stable income and small risk of failure and those could achieved by contributing in CF. Furthermore, large household size provided more labor since $\mathrm{CF}$ is labor intensive on the farmer part (Swain, 2012). In addition, farmers with large household size tended to participate in resourceproviding contract such as broiler CF (Ba et al., 2019). However, in a marketing contract, household size appeared to have insignificant effect to farmers' participation in CF (Bellemare and Bloem, 2018).

Education had a positive effect on farmers' decision to play a part in CF. This is in line with the results of studies by Freguin-Gresh et al. (2012); Ito et al. (2012) and Pandey (2016). The odds ratio value was 2.166 , denoting that farmers with higher education would have more tendencies to take part in CF by 2.166 times more, compared to farmers with lower education levels, assuming that other variables were constant. Farmers with higher education believed that participating in $\mathrm{CF}$ would contribute to more efficient broiler production to reduce losses. On the other hand, farmers with lower education would assume that CF was a highly complex concept to be applied in the business of broilers.

Holly Wang et al. (2011) have stated that higher levels of formal education can increase farmers' awareness on the importance of participating in CF. However, a consensus in international literature regarding the sign and significance of education on CF participation has not been available. Wang et al. (2014) have uncovered that education is an insignificant predictor of $\mathrm{CF}$ participation. Meanwhile, Simmons et al. (2005) have specified that the effect of education on CF participation depends on the type of contracted commodities. This explains that education has a nonlinear effect to CF participation (Miyata et al., 2009)

Risk aversion level did not have any significant effect on farmers' decision to participate in CF. This finding is corresponding to the results of the studies by Guo et al. (2005); Guo and Jolly (2008); Vassalos and Li (2016). The results of interview have showed that farmers who did not play a part in $\mathrm{CF}$ also had a desire to do so, but there were conditions that they could not fulfill. They assumed that the minimum scale of farming was large. On the contrary, farmers who already participated in CF seemed to have a tendency to be independent, but they had some difficulties in preparing a large amount of capital in the beginning of the production process.

Both groups had propensity whether they wanted to participate or did not take part in CF. The farmers' tendency caused their attitude in avoiding risk to become slightly unclear, and thus this directly affected the analysis of farmers' risk aversion level. This ambiguity has been discussed by Peng and Pang (2019), who found that farmers' risk aversion increased with the farm size. In contrast with our research finding, Lyu and Barré (2017); Belissa et al. (2019) and Yanuarti et al. (2019) have found that farmer's risk aversion level had a significant influence towards their decision to participate in insurance. Farmers with high risk aversion would be willing to join agricultural insurance.

Risk preference had a positive effect, implying that when the average point was greater, the farmers were more likely to participate in $\mathrm{CF}$. The result is in agreement with the Ghanaian pineapple farmers' contract choices (Fischer and Wollni, 2018). The odds ratio value was 14.149 , signifying that farmers with a high-risk preference had a higher tendency to be involved in CF 14.149 times compared to farmers who had lower risk preference with assumptions that other variables were constant. Primary data indicate that when the farmers' risk preference was lower, the farmers would be more willing to practice farming independently, including the stages from the capital preparation until the marketing process of broilers. If there was not any price risk, independent farmers would be able to generate maximum profit that was higher that the profit of those who took part in CF because the selling price of independent farmers would be higher. Moreover, independent farmer would not have to 
share their profit with the company. The results of farmers' risk preference are presented in Table 7.

Table 7. The risk preference distribution of broiler farmers against price risks in broiler farming in Jember

\begin{tabular}{crrrr}
\hline Risk & \multicolumn{3}{c}{ Total (people) } & Percentage (\%) \\
\cline { 2 - 5 } preference & CF & Non-CF & CF & Non-CF \\
\hline Risk taker & 5 & 22 & 7 & 32 \\
Risk neutral & 0 & 3 & 0 & 4 \\
Risk averese & 30 & 10 & 43 & 14 \\
\hline \multicolumn{1}{c}{ Total } & 35 & 35 & 50 & 50 \\
\hline
\end{tabular}

The results of logistic regression analysis have revealed that the variables that significantly affected the farmers' decision to participate in $\mathrm{CF}$ were age $\left(\mathrm{X}_{1}\right)$, chicken population $\left(\mathrm{X}_{2}\right)$, number of household members $\left(\mathrm{X}_{3}\right)$, education $\left(\mathrm{X}_{4}\right)$ and risk preference $\left(\mathrm{X}_{6}\right)$. Whereas, variable that did not significantly put effect on farmers' decision to partake in $\mathrm{CF}$ was risk aversion level $\left(\mathrm{X}_{5}\right)$.

\section{CONCLUSIONS}

The significant factors influencing farmers' decision to participate in CF were age, farm size, household size, education and farmer risk preference. Meanwhile, farmer risk aversion level was found insignificant. From those significant variables, age had negative coefficient while the others had a positive effect on farmers' decision to participate in CF. This study concludes that risk aversion level does not have any statistically significant effect on farmers' decision to be involved in CF. The effect of risk aversion level might be confounded with other variable such as age and education. Based on the results of this study, the effort to expand CF participation should focus more on young and educated farmers who have large farm size.

\section{REFERENCES}

Akinola, B. D. (2014). Risk Preferences and Coping Strategies among Poultry Farmers in Abeokuta Metropolis, Nigeria. Global Journal of Science Frontier Research: D Agriculture and Veterinary, 14(5). Retrieved from https:// publication.babcock.edu.ng/asset/docs/public ations/AGRI/9512/4363.pdf

Arumugam, N., Arshad, F. M., \& Mohamed, Z. (2011). Determinants of Fresh Fruits and Vegetables (FFV) Farmers' Participation in
Contract Farming in Peninsular Malaysia. International Journal of Agricultural Management and Development (IJAMAD), I(2), 65-71. Retrieved from https://iranjour nals.nlai.ir/1231/article_325729.html

Ba, H. A., de Mey, Y., Thoron, S., \& Demont, M. (2019). Inclusiveness of contract farming along the vertical coordination continuum: Evidence from the Vietnamese rice sector. Land Use Policy, 87(May 2018), 104050. https://doi.org/10.1016/j.landusepol.2019.104 050

Belissa, T. K., Lensink, R., \& van Asseldonk, M. (2019). Risk and ambiguity aversion behavior in index-based insurance uptake decisions: Experimental evidence from Ethiopia. Journal of Economic Behavior \& Organization, (Article In Press). https://doi.org/10.1016/j.je bo.2019.07.018

Bellemare, M. F., \& Bloem, J. R. (2018). Does contract farming improve welfare? A review. Word Development, 112, 259-271. https://doi. org/https://doi.org/10.1016/j.worlddev.2018.0 8.018

Boadu, F. O. (2016). Chapter 4 - Agricultural Production and Share Contracts. Agricultural Law and Economics in Sub-Saharan Africa, 115-140. https://doi.org/10.1016/b978-0-12-8 01771-5.00004-6

Badan Pusat Statistik, [BPS]. (2014). Analisis Rumah Tangga Usaha Peternakan di Indonesia (H. Marhaeni, ed.). Jakarta: Badan Pusat Statistik. Retrieved from https://media. neliti.com/media/publications/48579-ID-anali sis-rumah-tangga-peternakan-di-indonesia-ha sil-survei-rumah-tangga-usaha-pe.pdf

Fischer, S., \& Wollni, M. (2018). The role of farmers' trust, risk and time preferences for contract choices: Experimental evidence from the Ghanaian pineapple sector. Food Policy, 81(October), 67-81. https://doi.org/10.1016/ j.foodpol.2018.10.005

Franken, J. R. V., Pennings, J. M. E., \& Garcia, P. (2012). Measuring Risk Attitude and Relation to Marketing Behavior. AAEA Annual Meeting. Seattle, Washington. Retrieved from https://www.researchgate.net/publication/254 384525_Measuring_Risk_Attitude_and_Relat ion_to_Marketing_Behavior 
Freguin-Gresh, S., D'Haese, M., \& Anseeuw, W. (2012). Demythifying contract farming: Evidence from rural South Africa. Agrekon, 51(3), 24-51. https://doi.org/10.1080/030318 53.2012.749567

Government Regulation. (1997). Concerning Partnership (State Gazette of the Republic of Indonesia Number: 44 of 1997, Retrieved from http://www.bpkp.go.id/uu/filedownload/4/69/ 1374.bpkp

Guo, H., \& Jolly, R. W. (2008). Contractual arrangements and enforcement in transition agriculture: Theory and evidence from China. Food Policy, 33(6), 570-575. https://doi.org/ 10.1016/j.foodpol.2008.04.003

Guo, H., Jolly, R. W., \& Zhu, J. (2005). Contract Farming in China: Supply Chain or Ball and Chain? Minnesota International Economic Development Conference, 51. Retrieved from https://www.researchgate.net/publication/239 754412_Contract_Farming_in_China_Supply _Chain_or_Ball_and_Chain

Holly Wang, H., Zhang, Y., \& Wu, L. (2011). Is contract farming a risk management instrument for Chinese farmers?: Evidence from a survey of vegetable farmers in Shandong. China Agricultural Economic Review, 3(4), 489-504. https://doi.org/10.11 08/17561371111192347

Hu, W.-Y. (2012). Effect of Contract Farming on the Farmers' Average Return - The Case of the Grain Industry in the USA. Selected Paper Prepared for Presentation at the Agricultural and Applied Economics Associations (AAEA) 2012 Annual Meeting, Seattle, Washington. Retrieved from https://ageconsearch.umn.edu/ record/124659/files/Hu384.pdf

Ito, J., Bao, Z., \& Su, Q. (2012). Distributional effects of agricultural cooperatives in China: Exclusion of smallholders and potential gains on participation. Food Policy, 37(6), 700-709. https://doi.org/10.1016/j.foodpol.2012.07.009

Kamble, S. S., Gunasekaran, A., \& Gawankar, S. A. (2020). Achieving sustainable performance in a data-driven agriculture supply chain: A review for research and applications. International Journal of Production Economics, 219(March 2019), 179-194. https: //doi.org/10.1016/j.ijpe.2019.05.022
Key, N. (2005). How much do farmers value their independence? Agricultural Economics, 33(1), 117-126. https://doi.org/10.1111/j.1574-0862. 2005.00339.x

Lyu, K., \& Barré, T. J. (2017). Risk aversion in crop insurance program purchase decisions Evidence from maize production areas in China. China Agricultural Economic Review, 9(1), 62-80. https://doi.org/10.1108/CAER04-2015-0036

MacDonald, J. M., \& Korb, P. (2012). Agri cultural Contracting Update: Contracts in 2008. USDA-ERS Economic Information Bulletin No. 72. https://doi.org/10.2139/ssrn.2 114442

Mao, H., Zhou, L., Ifft, J., \& Ying, R. Y. (2019). Risk preferences, production contracts and technology adoption by broiler farmers in China. China Economic Review, 54, 147-159. https://doi.org/10.1016/j.chieco.2018.10.014

Miyata, S., Minot, N., \& Hu, D. (2009). Impact of Contract Farming on Income: Linking Small Farmers, Packers, and Supermarkets in China. World Development, 37(11), 1781-1790. https ://doi.org/10.1016/j.worlddev.2008.08.025

Otsuka, K., Nakano, Y., \& Takahashi, K. (2016). Contract Farming in Developed and Developing Countries. Annual Review of Resources Economics, 8(12), 1-24. https://doi. org/10.1146/annurev-resource-100815-09545 9

Pandey, A. P. (2016). Socio Economic Factors of Contract Farming: A Logistic Analysis. IRAInternational Journal of Management \& Social Sciences, 3(3), 749-762. https://doi.org/ 10.21013/jmss.v3.n3.p31

Peng, H., \& Pang, T. (2019). Optimal strategies for a three-level contract-farming supply chain with subsidy. International Journal of Production Economics, 216(June), 274-286. https://doi.org/10.1016/j.ijpe.2019.06.011

Pusat Data dan Sistem Informasi Pertanian. (2018). Statistik Konsumsi Pangan Tahun 2018. 1-102. Retrieved from http://epublikasi. setjen.pertanian.go.id/arsip-perstatistikan/ 163-statistik/statistik-konsumsi/599-statistikkonsumsi-pangan-tahun-2018

Schipmann, C., \& Qaim, M. (2011). Supply chain 
differentiation, contract agriculture, and farmers' marketing preferences: The case of sweet pepper in Thailand. Food Policy, 36(5), 667-677. https://doi.org/10.1016/j.foodpol.20 11.07.004

Simmons, P., Winters, P., \& Patrick, I. (2005). An analysis of contract farming in East Java, Bali, and Lombok, Indonesia. Agricultural Economics, 33(SUPPL. 3), 513-525. https:// doi.org/10.1111/j.1574-0864.2005.00096.x

Sunarno, Rahayu, E. S., \& Purnomo, S. H. (2017). Faktor-Faktor Yang Mempengaruhi Produksi Ayam Broiler Di Kabupaten Wonogiri. Prosiding Seminar Nasional \& Internasional, 1(1), 455-466. Retrieved from https://jurnal. unimus.ac.id/index.php/psn12012010/article/ view/2326

Swain, B. B. (2012). Determinants of Farmers' Participation in Contract Farming: The Cases of Gherkin and Paddy Seed in Andhra Pradesh, India. Millennial Asia, 3(2), 169-185. https:// doi.org/10.1177/097639961200300203

Ton, G., Vellema, W., Desiere, S., Weituschat, S., \& D'Haese, M. (2018). Contract farming for improving smallholder incomes: What can we learn from effectiveness studies? World Development, 104, 46-64. https://doi.org/10. 1016/j.worlddev.2017.11.015

Vassalos, M., \& Li, Y. (2016). Assessing the impact of fresh vegetable growers' risk aversion levels and risk preferences on the probability of adopting marketing contracts: A Bayesian approach. International Food and Agribusiness Management Review, 19(1), 2542. http://dx.doi.org/10.22004/ag.econ.23083 2

Wainaina, P. W., Okello, J. J., \& Nzuma, J. M. (2014). Blessing or evil? Contract farming, smallholder poultry production and household welfare in Kenya. Quarterly Journal of International Agriculture, 53(4), 319-340. http://doi.org/10.22004/ag.econ.199252

Wang, H. H., Wang, Y., \& Delgado, M. S. (2014). The transition to modern agriculture: Contract farming in developing economies. American Journal of Agricultural Economics, 96(5), 1257-1271. https://doi.org/10.1093/ajae/aau0 36

Widjayanti, F. N., \& Rizal, M. (2014). Sistem kemitraan dalam usahatani peternakan ayam broiler di Kabupaten Jember. Implementation Science, 39(1), 1-15. Retrieved from http:// ejournal.umpwr.ac.id/index.php/surya-agrita $\mathrm{ma} /$ article/view/3101/3275

Yanuarti, R., Aji, J. M. M., \& Rondhi, M. (2019). Risk aversion level influence on farmer's decision to participate in crop insurance: A review. Agricultural Economics (Czech Republic), 65(10), 481-489. https://doi.org/ 10.17221/93/2019-AGRICECON 